\author{
VI International Forum on Teacher Education
}

\title{
Social Partnership as a Factor in Increasing the International Competitiveness of Pedagogical Universities
}

\author{
Nadia G. Yusupova (a), Galina N. Skudareva * (b) \\ (a), (b) SEI HE MO «State University of Humanities and Technology», 142611, Orekhovo-Zuevo (Russia), \\ 22 Green street, Skudarevagalina@yandex.ru
}

\begin{abstract}
The relevance of the research stems from the fact that the subject of public and professional discussions is indicated by the competitiveness of pedagogical universities, searching for new solutions and opportunities of social partnership based on international experience, using the methods of context, dynamic and theoretical analysis.

The theoretical background of this problem made it possible to formulate the concepts of "competitiveness" and "social partnership", as a system of civilized social relations, highlighting universal joint activities of social subjects to achieve overlapping interests, based on the principles of democracy, publicity, openness, respect for the rights and freedoms of all parties of the international social interaction.

The article reveals the processes of the international social partnership of a regional university with its foreign partners. It determines the commitment to achieving the goals and solving problems associated with the formulation of international priorities, increasing the university international reputation, the confidence of foreign social partners, ensuring international effects. Successful international educational partnership and practice, implemented by GGTU, presents the project " Spanish educational content ." It included two significant events: "Educational tour to universities of Spain" and organization of the international Russian-Spanish Forum "Education without Borders: science, experience, technology."

The practical significance of this study is aimed at enhancing GGTU quality of pedagogical education and increasing international competitiveness of a regional pedagogical University, and the development of professional skills of teachers, the intensification of international sociocultural partnership and communication of scientists and practitioners in the world.
\end{abstract}

Keywords: social partnership, international competitiveness, university competitiveness, pedagogical university, education, society.

(C) 2020 Nadia G. Yusupova, Galina N. Skudareva

This is an open access article distributed under the terms of the Creative Commons Attribution License (CC BY 4.0), which permits unrestricted use, distribution, and reproduction in any medium, provided the original author and source are credited.

Published by Kazan federal university and peer-reviewed under responsibility of IFTE-2020 (VI International Forum on Teacher Education)

\footnotetext{
* Corresponding author. E-mail: Skudarevagalina@yandex.ru
} 


\section{Introduction}

Relevance. The increasing complexity of the requirements for professional development of a teacher is determined by the most important strategic guidelines of modern educational policy. At all times Russian educational policy has been an inseparable segment of the Russian political space, which has not been lately in the most comfortable international conditions, undergoing economic sanctions, political and social pressure, etc. (Skudareva \& Shishova, 2013).

The sphere of education is the political stronghold that promotes Russia's national interests through the international diplomacy of Russian universities and international social partnership. The strategic constructs of Russian educational policy are based on priorities orienting the system of modern education towards objective indicators and competitive results (Skudareva \& Shishova, 2013).

Our university ordained political - educational situation, which was later indicated in speech of Pedro Duque, Spanish Minister of Science, the Kingdom of Spain : "Russia and Spain will hold a science crossyear in 2019 or 2020 . Let's try to get it started in 2019 . We want to expand our ties. A few years ago it was a bilateral tourism year, and now lets spend a year of general education, higher education and science. There are many projects that we should start with Russia..." (Hakimova, 2018, p. 24).

At that time, eight Spanish and Russian universities announced about their intention to create a new association, to increase the level of academic cooperation and strengthen cultural ties between the two countries. As noted in the Center of Russian-Spanish Cooperation , the new alliance will be the first in the history of two countries. The project was presented on January 17 at the Gaidar Forum in Moscow. RANEPA, Tomsk State University, MIS\&A and the All-Russian Academy of Foreign Trade on the Russian side and Madrid University after Carlos III , University of Oviedo, University of Valencia and the University of Rovira and Virchalia on the Spanish side entered the alliance. The project team emphasizes the extensive opportunities for social partnership and expressed confidence in its success, thanks to the diversity of higher education institutions and a high level of educational services. It is planned that the number of participants will increase, and the alliance will become a platform for the conduct of civil dialogues between Russia and Spain in various fields.

The process of increasing the international competitiveness of Russian universities demonstrates high efficiency: the number of homeland universities of the highest ranks in international ratings is growing. More and more often the subject of public and professional discussions becomes the problem of pedagogical universities competitiveness, designed to search for new solutions and new opportunities for social partnership, taking into account international experience. 
It seems appropriate to consider the theoretical reasons of the problem and analyze theoretically the main concepts such as "social partnership" and "competitiveness of the university ".

\section{Literature Review}

Some researchers, such propose a sufficiently broad definition of social partnership, examining this phenomenon as a universal joint activity of social subjects to achieve overlapping interests .

Nabiulina characterizes social partnership in education as a unity of educational institutions relations, employers' associations, trade unions and authority structures on the basis of contracts and agreements in order to give future development of the education system, human personnel resource development of the country, formation of socially active educated person, economic and spiritual progress of society, based on variety of agreements, contracts and regulation mechanisms of social dialogues (2003).

The political basis of social partnership is the developed forms of democracy, when the fundamental rights and freedoms of the individual are declared and reliably guaranteed by the state. Partnership can develop successfuly only in the conditions of wide publicity and observation of rights. The main task of the social partnership is to accommodate the differences of its subjects, in carrying out the agreed policy which by mutual concessions have contributed to the adoption of mutually acceptable decisions and freedoms for all the parties of social interaction (Nabiulina, 2003).

Burljaeva (2010) defines social partnership as a system of civilized social relations aimed at protecting the interests of coordination and representation of different social groups, strata, classes, associations, public authorities, local self-governments, commercial and non-profit organizations, government agencies.

The parties of social partnership are all participants of mutual actions, that implement the most important role behavior model, and the mechanism for implementing social partnership is a procedure for coordinating the interaction of the parties in the process of discussion, adoption and implementation of planned activities (Burlyaeva, 2010).

Gainullina's thesis analyzed social partnership as the ideology of a democratic society on the regulation of social and political relations, for the achievement of social and political stability: "... social partnership as a new type of interaction between social forces arises as a public need and necessity only at certain stages of the industrial and post-industrial society; differentiation in society and conflict increasing demand inevitably the transition to partnership, cooperation, expanding the area used for new type of interaction " (1999). 
Social partnership researchers represent it as a system of civilized social relations, highlighting in its essence universal joint activities of social subjects to achieve overlapping interests, based on the principles of democracy, publicity and transparency, respect for the rights and freedoms for all aspects of social interaction .

The Decree of the President of Russia Putin "On the national goals and strategic tasks of the Russian Federation development in the period up to 2024" announced "global competitiveness of Russian education, the Russian Federation entering the ten top countries in the world on the quality of general education". The Decree stimulated expert community to debate, what should be considered "global competitiveness", and how it is defined and measured (2012).

Agranovich considers higher education in the context of the economics, based on the knowledge, as the most important factor in national competitiveness. It is there, that the most highly productive human capital is formed, where knowledge and innovations are produced. Therefore, the last decade is characterized by global competition in higher education. There is no coincidence that population coverage by higher education programs is growing worldwide at rates exceeding GDP growth: since 1970 it has increased by more than 6 times, while GDP - by more than 2 times (Agranovich, 2017).

In "Management of competitiveness of modern Russian University : status, challenges and response" researchers Latyshev, Pokholkov, Chervach, Shadsky formulated the concept of "university competitiveness ", which is understood as the university's ability to win the fight for the resources that are valued particularly by university positions in recognized international and homeland ratings" (2017).

Higher education is the factor affecting the economics of the developed countries in general and on the state's position in the global ranking of the competitiveness in particular. Moreover, the institutional impact of higher education on the competitiveness of the country can be traced in many areas - from objectively observable: the quality of human capital, the level of collaboration of leading universities and industry, the availability of scientists and engineers; to indirect: the rate of generation and innovation, the development of technological management ,technological transfer and others (Salmi \& Froumin, 2013).

The concept of higher education as an integral part of the competitive advantage of the country, along with an increase of the global rating importance, led to a qualitative change in the perception of the role and importance of universities by national governments and government departments (Rakitov, 2016).

Today, fundamental changes are taking place in the internal and external environment of universities, in the goals and nature of their activities, which require a new look at a university model, the search for ways to adapt it to these changes and, possibly, changes in universities organization paradigms and education in 
general (Wissema, 2009). Definitely it is worth agreeing with the opinion that the current situation of rapid globalization transforms education aims to correlate colleges and universities themselves to the needs of increasing their efficiency (Galazhinsky, 2017).

An important condition for increasing the effectiveness of universities is to reinforce incentives for the development of regional universities at the expense of the leading universities potential, as well as to create opportunities for increasing scientific productivity and technology transfer for the interests of the regions .

Based on the relevance of the problem and the results of theoretical analysis of the main concepts of the article, it seems possible to formulate the purpose of the study.

The purpose of the study: to identify the conditions for increasing the international competitiveness of a pedagogical university and to determine the role of social partnerships in this process .

The aim of the study is to formulate a logical question: what is the purpose of a pedagogical university international mission, that implements its activities in the regional educational space. To answer this question, it is necessary to analyze objectively the real conditions of its international activities.

The research methods identified:

- dynamic and contextual analysis of Spanish education system, as an international social partner, and the potential possibilities of State University of Humanities and Technology in increasing its international competitiveness ;

- $\quad$ direct and indirect monitoring of education in Spain;

- $\quad$ methods of organizing, summarizing and comparing the information received.

\section{Results}

As a result, contextual and dynamic analysis revealed that taking into account the present-day varieties of strategic educational tasks and political challengies for modern pedagogical institute formulates for itself very ambitious objectives:

- $\quad$ step up integration into the world educational space based on the export of educational services;

- $\quad$ organize an international recruitment of the teaching staff, by inviting foreign experts in the field of IT- technologies for the development of distance learning on the basis of high school; 
- involve foreign language speakers for intensive teaching for the development of academic mobility of students, professors and teaching staff of the university;

- recruit foreign specialists in the field of pedagogy and psychology, specializing in the problem of giftedness and the problem of deviant behavior of students;

- $\quad$ establish the process of internationalization, concluding cooperation agreements with foreign universities and subjects of social partnership ;

- $\quad$ organize internships for the scientific, pedagogical and managerial staff of the university in leading foreign universities, scientific and educational centers abroad, giving priority to specialists in the field of IT- technologies (for developing competencies in the field of distance education);

- $\quad$ organize foreign students training of all implemented in the university branches, giving priority to the Russian language and pre-school education teacher training, who can implement the concept of bilingual education in pre-school educational institutions in Moscow region.

At the same time the strategic goal of regional pedagogical high school is associated with positioning themselves to foreign social partners as the University, accumulating the best regional and nation-wide educational practices and having opportunities to broadcast them to all aspects of Moscow region and Russia education system, which will create a united informational space of training and communication of teachers of various formats, scales and levels (Twelve solutions for the new education, 2018).

However, it is objectively necessary to note that the international reputation of regional pedagogical universities is in its infancy, which is complicated by the current political situation. The most common problems when foreign social partners are:

- $\quad$ subjected to stereotypes about Russia and Russians, often negative;

- $\quad$ distanced culturally and politically;

- $\quad$ belong to a different sociocultural and educational environment;

- $\quad$ mismatched of standards, measures, rules, perceptions;

- $\quad$ state of uncertainty, often having a shortage of information about the presented educational object;

- $\quad$ search for the best product or educational service for minimum resource investment. 
It is under the named conditions that the regional pedagogical university assumes the obligation to determine strategic goals and tasks related to the formulation of international priorities, the growth of the university international reputation, the strengthening of foreign social partners trust and the provision of international effects.

Here it becomes more appropriate to illustrate the thesis formulated above as successful educational practices of the international foreign social partnerships and is implemented in the State Institution of Higher Education of the Moscow region "State University of Humanities and Technology" (GGTU) in Orekhovo-Zuevo, Russia.

In 2019, GGTU launched the project "Spanish educational content", which foreign social partner became Rrussian school in Marbelia, Kingdom of Spain (Director Chistyakova). Its aims are :

- intensification of GGTU integration into the global educational space based on the export of educational services;

- $\quad$ learning successful practices in Spanish education;

- $\quad$ presentation of the educational system experience by the Russian pedagogical community in the Kingdom of Spain;

- $\quad$ establishment of the internationalization process in the framework of social partnership through the conclusion of cooperation agreements with universities in Spain;

- the organization of university internships for scientific, pedagogical and managerial personnel in leading Spanish universities, scientific and educational centers of Spain ;

- $\quad$ implementation of recruiting foreign experts in the field of pedagogy and

psychology, specializing in the problem of giftedness and bilingualism.

The current Russian political and educational situation, aimed at the convergence and integration of the Russian and Spanish education described above, defined the urgency of the choice and the theme of the project and its content as follows:

- the education system of the Kingdom of Spain is unique, the concept of "A Happy Child" is being implemented at all levels 
- GGTU provider's interests in Spain are realized by the Union of Russian compatriots in Spain;

- $\quad$ Spanish educational organizations provide an opportunity for the students

of GGTU pedagogical class to present their experience in Russian school №1 of Marbelia and at the Pedagogical Faculty of University in Cadiz.

The substantial components of the project included two significant events:

- $\quad$ Educational tour to universities in Spain;

- Organization and conduction of the International Russian-Spanish Forum "Education without Borders: science, business, technology" - 2019.

In this article, we will touch on the descriptions of the educational tour to the universities of Spain in January 2019.

"The aim of the Russian delegation visit to the Iberian Peninsula was the establishment of international contacts and partnership agreements with the leading educational institutions in Spain. The delegation planned to visit Madrid, Burgos, Valladolid, Cadiz, Granada and Marbelia ... "- these words commented on our tour in the newspaper SUR (in Russian) in Andalusia and its chief editor Elena Hakimova (2018).

In the course of an educational tour to universities of Spain, social partnership in the field of education and science was promoted, and the cooperation agreements were signed in the cities of Burgos, Valladolid, Malaga, Cadiz, Granada.

It is possible to offer the following information as a reference. The University of Burgos is one of the youngest Spanish universities, which trains nine thousand students. It is a public institution of higher education of research and international experience, that has the European recognition.The successive University proposals are united by double diploma, master's and doctor"s programs, online - training (post-graduate and doctoral degree). The university offers English language instruction and bilingual programs. In total, it implements up to ninety disciplines taught in English. University of Valladolid began its history as the branch of the University of Valencia, which was opened in 1241. Since the Middle Ages, it has been one of the most important centers of spanish science and education. Currently, there are about 22 thousand students. The universities of Cadiz and Granada are also the oldest and largest Research Institutions, attended by 35,000 students and 88,000 students, respectively. 
The Visit to the offices of Roscooperation in Spain and reception by Counselor of the Russian Federation Embassy to the Kingdom of Spain Sokolov, emphasized establishing communication with the delegation of our university.

An indelible impression was made at the meeting with the sworn translator of the King of Spain, the Ministry of Foreign Affairs of Spain, doctor of philology, Honorary Professor of the Russian Academy of Sciences Maria Sanchez Puig. The GGTU delegation was hosted by the family of the official royal translator Maria Sanchez Puig and the WWII veteran from among the Spanish children brought to Russia, Manuel Arce Porres, a pupil of the Obninsky orphanage, and the author of numerous books about Russia. During the meeting the parties discussed the prospects of GGTU cooperation with Maria Sanchez Puig in the field of philological education.

Communication with the Rectorate of the University of Burgos: Vice-Rector for International Relations Helena Domingo, Director of the International Relations department Christina Basurto, the dean of Social Sciences and Humanities faculty Ignacio de Mata and the professor of Translation Studies faculty Antonio Garcia revealed the ways and forms of social partnership in almost all the directions of Russian and Spanish universities intergration. During the meeting with the vice-rector for Internationalization of Valladolid University, Paloma Castro revealed GGTU opportunities in the implementation of mastery programs of international pedagogical trend in English.

The meeting with the Director General for International Relations, Juan Carlos Garsia and Andres Arribas Santana, Director of Russian -Spanish University Center at University of Cadiz allowed to discuss the issues and proposals for mutually beneficial cooperation, to satisfy requests of both sides. They were particularly interested in our Pedagogical Faculty, as they have the same successfully developing faculty too. Moreover, the pedagogical class of GGTU in Elektrostal received the invitation to conduct master -classes at the forum "Education Without Borders. "

A business conversation with the Vice-Rector for Internationalization Dorothy Kelly and Enrique Kero, the dean of the Translation Studies Faculty , Director of the Russian Fund Center "Russian world", revealed the interest in development of cooperation with GGTU Pedagogical Faculty and Faculty of Pharmacy .

As interim results of GGTU educational tour in Spain, the agreements reached can be noted in the terms of:

- exchanging of students and teachers (Burgos, Cadiz); 
- training in international master's programs in English (Valladolid);

- attracting Spanish speakers to employment at GGTU (Valladolid);

- studying the activities of our Pharmacy Faculty (Granada);

- internships of professors and teaching staff of GGTU ( yet without the knowledge of Spanish ) with a tutor accompaniment (Cadiz);

- obtaining double diplomas of graduate and postgraduate programs (Cadiz, Burgos);

- study of early pedagogical motivation experience in pedagogical classes (Cadiz).

Some agreements on exchange of students for undergraduate and graduate programs, scientific internships for teachers, and the possibility of employing teaching staff of Burgos at GGTU were made.

Organization and conduction of the International Russian-Spanish forum "Education Without Borders: Science, Experience, Technology" is the second substantial component of the project "Spanish educational content " .

International Russian-Spanish Forum "Education without Borders: Science, Experience, Technology" held in Marbelia, Kingdom of Spain was organized by the Moscow region Ministry of Education, GGTU (Orekhovo-Zuevo), representatives of " Roscooperation " in the Kingdom of Spain, the Union of Russian Compatriots Organizations in Spain, Russian school № 1 in Marbelia (Spain). The Forum speakers on the issues of tutoring education were Russian and foreign scientists and practitioners .

The preparation for the Forum was held in the conditions of social partnership of teachers, scientists, and intellectual elite of Russia, Spain, France, Germany, Morocco, Poland and other countries participants. At the plenary session the participants discussed the problems and perspectives of education in different countries, presenting foreign experience as a resource for innovation in homeland education; objectified the ways of iternational social partnership integration in science and education. After the plenary session the work of discussion platform began: "Global trends forming language competence", " New strategies of modern education" and the Round Table "Teaching Russian as a foreign language", where successful experience and best educational practices were represented.

A business trip to Spain was organized to improve the university teaching staff qualification and increase the level of additional vocational training for managers and pedagogical staff. To develop the training of 
university scientific-pedagogical and administrative personnel of the Moscow region, the International Russian-Spanish Forum "Education without Borders: science, experience, technology" on the theme: "European standards of education and pedagogical personnel" was held in the leading universities, scientific-educational centers and schools of Spain.

\section{Discussion}

In general, the Forum "Education without Borders " has given a new impulse to the improvement of teachers professional mastership, activization of international social partnership but it has also widened the borders of scientific and sociocultural communication of scientists and practitioners all over the world. The results of the Forum and GGTU international mission in Spain is a valuable resource for development of social partnership and improvement of the regional pedagogical high school international competitiveness. This experience should be analyzed and used in further international activities. Its presentation was held in the format "Spanish raspsody" at the International Salon of education at the Exhibition of Achievements of the National Economy in Moscow.

Thus, long-term prospects for the development of relations between GGTU and educational institutions of Spain made it possible to formulate the following conclusions:

- dynamic and contextual analyzes of Spanish education system

allowed to recognize its classical orientation, innovativeness, uniqueness, originality;

- internationalization processes in the education system of Spain are in active state and are focused on further international development, including GGTU ;

- provider of GGTU interests in Spain are The Unity of Russian Compatriots organizations in Spain, other political and public organizations in Spain and Russia, Russian school № 1 in Marbelia ;

The results of the work will have the following formats:

- accumulation and presentation of the best educational practices of Spain in the pedagogical laboratory of GGTU and their subsequent inclusion in the educational process;

- development and implementation of a new Russian-Spanish educational project in GGTU;

- professional development of the university teaching staff and leaders supplementary vocational training of the Moscow region, taking into account the experience of the Spanish education system. 
Thus, there is no doubt about the importance of using the results of "Spanish Educational Content" project to improve the quality of teachers education at GGTU and to increase the international competitiveness of a regional university.

\section{Conclusion}

The subject of public and professional debates is the problem of pedagogical universities' competitiveness, designed to search for new solutions and new opportunities for social partnership based on international experience.

The actualization of the problem formulated in this article allowed us to look at it in many aspects. The theoretical background of the problem allows us to formulate the main concepts of the study "social partnership" and "competitiveness"; to identify the problems complicating the processes of an international social partnership of a regional university with foreign entities; to determine the obligation for achieving the goals and definition of tasks associated with the formulation of international priorities, increasing the University international reputation, strengthening the confidence of foreign social partners to ensure international effects. Successful educational international practices and foreign social partnership, implemented by GGTU, are presented in the project " Spanish educational content ." The substantive components of the project included two significant measures for taking: "An educational tour to universities of Spain" and the organization and conduction of the International Russian-Spanish forum "Education without borders: science, experience, technology".

The result of the Educational tour to universities of Spain, the agreement on students exchange, scientific training of teachers, the possibility of Spanish teachers employment in GGTU. International RussianSpanish Forum "Education without Borders: science, experience, technology" has given a new impetus to master the professional skills of teachers, enhancing international social partnership and expanding boundaries of the scientific and socio-cultural communication of scientists and practitioners worldwide.

All the above-mentioned results were achieved due to the social partnership as a system of civilized public relations of social subjects based on mutually overlapping interests, principles of democracy, transparency, openness, respect for the rights and freedoms of all parties to international social interaction.

\section{References}

Agranovich, M. L. (2017). Indicators of sustainable development goals in the area of used nation and national educational policy. Voprosy Obrazovaniya [About education issues], 4, 242-264. 
Burlyaeva, V. A. (2010). The culture of social partnership as a condition for the modernization processes of the modern Russian society: a condition and prospects for further development (Doctoral dissertation). Maykop: Adyghe State University.

Decree of the President of the Russian Federation May 7, 2012 No. 599. (2012). On measures to implementation of the state policy in the sphere of education and science. Retrieved from https //rg.ru/2012/05/09/nauka-dok.html

Gainullina, F. I. (1999). Formation of system of social partnership in the Republic of Tatarstan (Doctoral dissertation). Moscow: The Academy of Labor and Social Relations.

Galazhinsky, E. V. (2017). Demanded competence of heads of universities: the world of the stems trends and Russian processes in education. Universitetskoe upravlenie: praktika i analis [University Management: great to tick and analysis], 21(2), 6-8.

Hakimova, E. (2018). Education without borders. Moscow: Academy.

Knight, A. (2001). Exercise and osteoarthritis of the knee (Unpublished master's dissertation). Auckland: Auckland University of Technology.

Kuzminov, Ya. I., \& Frumin, I. D. (2018). Twelve solutions for new education: report of the Center for Strategic Research and the Higher School of Economics. Moscow: National Research University "Higher School of Economics".

Latyshev, A. S., Poholkov, Yu. P., Chervach, M. Yu., \& Shadskaya, A. N. (2017). Competitor management about the ability of a modern Russian university: status, challenges and answers Universitetskoe upravlenie: praktika $i$ analiz[University management: practice and analysis], 21(5), 1-15.

Nabiulina, N. M. (2003). Formation and development of social partnership in the field of education (Ph.D. dissertation). Moscow: Russian Presidential Academy of National Economy and Public Administration.

Rakitov, A. I. (2016). The integration of education and science as a global problem. Integratsiya obrazovaniya [Integration of education], 20(3), 331-341.

Salmi, D., \& Froumin, I. D. (2013). As States Seek International Competitiveness of Universities: Lessons for Russia. Voprosy Jazykoznanija [Topics in the study of language], 1, 25-68. 
Skudareva, G. N, \& Shishova, G. G. (2013). Social order form as a phenomenon of modern Noah pedagogical reality. Vospitanie shkolnikov [Education of school children], 8, 3-10.

Wissema, J. G. (2009). Towards the third generation university: Managing the university in transition. Cheltenham: Edward Elgar Publishing. 